Review

\title{
Depleted Uranium and Its Effects on Humans
}

\section{Zdeněk Hon *, Jan Österreicher ${ }^{\dagger}$ and Leoš Navrátil ${ }^{\dagger}$}

Department of Health Care Disciplines and Population Protection, Faculty of Biomedical Engineering, Czech Technical University in Prague, nam. Sitna 3105, 27201 Kladno, Czech Republic;

E-Mails: j.osterreicher@seznam.cz (J.Ö.); leos.navratil@fbmi.cvut.cz (L.N.)

$\dagger$ These authors contributed equally to this work.

* Author to whom correspondence should be addressed; E-Mail: zdenek.hon@fbmi.cvut.cz; Tel.: +420-224-359-902; Fax: +420-312-608-204.

Academic Editor: Marc A. Rosen

Received: 27 January 2015 / Accepted: 1 April 2015 / Published: 8 April 2015

\begin{abstract}
The article summarizes contemporary scientific knowledge of depleted uranium effects on human health due to its use in military conflicts. The discussion covers cases of minimal risk due to external irradiation resulting from the storage and handling of depleted uranium ammunition and, in contrast, important toxicological and radio-toxicological risks of late effects resulting from the inhalation and ingestion of dust particles produced by the burning of the core of the anti-tank ammunition.
\end{abstract}

Keywords: depleted uranium; human health; radio-toxicological risks

\section{Introduction}

Uranium has been part of our planet's crust since it was formed and is present in variable amounts in its rock, soil, air and water. Uranium enters our bodies via the air we breathe, the food we eat and the water we drink [1].

Uranium is a chemical element with the proton number 92 and a molar mass of $238.03 \mathrm{~g} / \mathrm{mol}$. It is an alpha-emitting, radioactive and silvery-white heavy metal. Natural uranium consists of three different isotopes $(99.284 \% \mathrm{U}-238,0.711 \% \mathrm{U}-235$ and $0.005 \% \mathrm{U}-234)$ with a specific activity of $0.68 \mu \mathrm{Ci} / \mathrm{g}$ [2]. All of the uranium isotopes are radioactive. Uranium also possesses a number of special characteristics. It has a high density $\left(19.07 \mathrm{~g} / \mathrm{cm}^{3}\right)$, only moderately lower compared to tungsten $\left(19.30 \mathrm{~g} / \mathrm{cm}^{3}\right)$ and 
higher compared to lead $\left(11.35 \mathrm{~g} / \mathrm{cm}^{3}\right)$. Metallic uranium is chemically considerably reactive; in powder form, it can be spontaneously ignited [3]. It is of importance to mention that in the human body, there is about $0.1 \mathrm{mg}$ of natural uranium [4], which is a natural component from exposure to uranium found in food, water and air.

For nuclear engineering purposes, uranium ore is used in a number of processes, and from its concentrate, enriched uranium is obtained, which is a basic raw material for the manufacture of fuel elements used in nuclear power facilities. The industrial process of enrichment separates natural uranium into enriched uranium (increased percentage of U-235) and depleted uranium (decreased percentage of U-235; the resulting concentration of U-235 ranges from about $0.2 \%$ to $0.3 \%$ ) The process of enrichment also increases the percentage of U-234 (thus, enriched uranium is more radioactive); depleted uranium (DU) has a decreased percentage of U-234 and is less radioactive [2]. Typically DU contains as much as $70 \%$ less U-235 and as much as $80 \%$ less U-234 than does naturally occurring uranium. DU radioactivity is about $40 \%$ lower than that of natural uranium (see Table 1). The specific activity of uranium alone in DU is only $14.80 \mathrm{~Bq}$ per mg compared with $25.40 \mathrm{~Bq}$ per mg for natural uranium (see Table 2). DU is approximately three million times less radioactive than Ra-226 found in luminescent clocks and watches and 10 million times less radioactive than Am-241 found in smoke detectors [4].

Table 1. DU isotopic abundance and characteristics (data from [5,6]).

\begin{tabular}{cccc}
\hline Nuclide & Half-Life (Years) & Relative Mass (\%) & Activity $(\boldsymbol{\mu C i} / \mathbf{g})$ \\
\hline $\mathrm{U}-238$ & $4.47 \times 10^{9}$ & 99.8 & $3.4 \times 10^{-1}$ \\
$\mathrm{U}-235$ & $7.04 \times 10^{8}$ & 0.2 & $4.3 \times 10^{-3}$ \\
$\mathrm{U}-234$ & $2.46 \times 10^{5}$ & 0.0006 & $3.7 \times 10^{-2}$ \\
\hline
\end{tabular}

Table 2. Comparison between the activity of natural uranium and DU (0.2\% U-235) (adapted from [5]).

\begin{tabular}{ccc}
\hline Nuclide & Natural Uranium Activity in $\mathbf{1 ~} \mathbf{~ m g} \mathbf{( B q} / \mathbf{m g})$ & Depleted Uranium Activity in $\mathbf{1 ~} \mathbf{~ g} \mathbf{( B q} / \mathbf{m g})$ \\
\hline U-238 & 12.40 & 12.40 \\
U-235 & 0.60 & 0.16 \\
U-234 & 12.40 & 2.26 \\
Total & 25.40 & 14.80 \\
activity & & \\
\hline
\end{tabular}

\section{Ammunition with Depleted Uranium}

For military purposes, DU is used in protective armor (for armor plating). In combination with its high density, the material is also suitable for the design of ammunition, since projectiles made of it can be smaller, achieve a higher velocity, have a longer firing range and can easily penetrate through armored plates [3]. In terms of using DU for penetrating ammunition, in addition to the large amounts available and low prices, there are advantageous mechanical characteristics, particularly its unusual density, which is considerably higher, even in comparison with tough and high-alloyed steel.

Ammunition with DU has a further advantage enhancing its efficacy. Uranium particles are ignited at the time of the penetration of a sub-caliber projectile through the armor, thanks to high temperatures. In this way, about $20 \%$ of the projectile mass is burnt and the burning fragments hit the vehicle interior, thus multiplying the destructive effect of the hit. The effect in the target or inside of the military vehicle 
is thus a combination of the kinetic energy and high temperature, acting not only by the temperature of the burning metal, but also secondarily by effects of the fire produced [3,7].

There are four main types of DU munitions acknowledged as being currently in circulation, the $25 \mathrm{~mm}, 30 \mathrm{~mm}, 105 \mathrm{~mm}$ and $120 \mathrm{~mm}$ anti-tank rounds. Small amounts of DU have been used in the manufacture of other munitions. A $30 \mathrm{~mm}$ round fired from a ground attack aircraft contains a $0.28 \mathrm{~kg}$ DU penetrator and $120 \mathrm{~mm}$ rounds fired from heavy tanks fire contain a $4.7 \mathrm{~kg}$ DU penetrator [8]. This information allows us, at least some general and preliminary estimates of the total amount of the DU used and dispersed and the potential problems for humans and environment in long-term military conflicts, where in addition, a whole complex of weapon systems is employed, and the majority applies ammunition with DU [9].

In civil applications, DU is used in stabilizers (counterweights) in aircrafts and boats, in the mining industry for the manufacture of drilling devices in petroleum mining, in shielding containers for rods of spent fuel from nuclear power plants, for the manufacture of radiation shielding (radiation shielding) in medicine, and many further commercial applications.

\section{Military Use of Depleted Uranium}

Weapons with DU were used to a considerable extent in the Persian Gulf War (1990-1991). About 50 metric tons of DU were fired during tank battles and 250 tons in air to ground attacks in Kuwait and southern Iraq over an area of about $20,000 \mathrm{~km}^{2}$ [7]. A considerable proportion of soldiers of the land contingent of the allied forces, who resided for a number of months in the territory of Saudi Arabia and then in Kuwait and Iraq, originally reported unexplained health problems, for which the term Gulf War syndrome was adopted [5]. All of the analyses agree that there was the presence of the combined effects of the desert environment with climatic conditions (characterized by high daily temperature changes and high temperatures in general), associated with the stress induced in military professionals, which was potentiated by the expected possibility of the use of chemical warfare agents on the part of Iraq. The health condition of part of the troops was negatively affected by the multiple fires of the Kuwait petroleum fields, the excess use of prophylactic antidotes and vaccines, along with effects resulting from the use of the ammunition with DU [9]. As a result of the Gulf War, there were also some complaints about an increasing incidence of cancer in the civil population in south Iraq [10].

A further mass use of the anti-tank ammunition containing a DU core in NATO military operations was encountered in Bosnia Herzegovina in the mid-1990s and in aircraft operations against the Federal Republic of Yugoslavia in association with the crisis in Kosovo and Metohija. Through the course of the war in Bosnia Herzegovina (1994-1995), U.S. aircraft fired some 10,000 rounds of ammunition with DU (2.75 tons), and in the course of the bombing of serbian and pro-serbian troops in Kosovo (1999) by the allies, more than 31,000 rounds of ammunition comprising about 8.5 tons of DU were shot $[3,10]$. In some individuals from several NATO countries, who participated in land operations in these military conflicts, and in the civil population, including children in the area involved, there was an enhanced incidence of malignant diseases of the hematopoietic system and the gastrointestinal tract. The term Balkan syndrome is associated with this [5]. Opinions of whether this is actually a consequence of using DU or not, however, differ. 
In spite of this, the continuing use of DU weapons in the war in Afghanistan (2002) and in the second Gulf War (2003) led to more intense research of their toxic and radiotoxic effects $[11,12]$.

\section{Health Risk Associated with Depleted Uranium}

Not only the use of the DU ammunition in war conflicts, but also the manufacture of the ammunition core itself (a metallic pointed cylindrical rod of DU) represent a potential safety and occupational hygiene hazard, since the production by conventional machinery is associated with a risk of ignition and the production of toxic and radiotoxic aerosols of the oxidation products. Contemporary industrial production is, however, able to manage these complex technological procedures to make them as safe as possible.

Handling associated with the DU ammunition presents no major problems, because during the incorporation of the core into the grenade and its assembling the possibility of external irradiation is negligible with respect to the range of the $\alpha$-radiation emitted.

Storing and handling of the ammunition before its use is relatively safe, but a variety of health and ecological problems are encountered after the hitting of the target, where the kinetic energy is vigorously converted to heat, due the material deformation and friction. The high temperature generated by the impact with steel ignites the surface of a DU penetrator, and the projectile sharpens as it melts making it better able to pierce heavy armor. The basic profile of healthcare and the rather irreversible damage in the crew of the warfare vehicle hit is a combination of mechanical trauma and extensive burns, primarily from the kinetic energy of the projectile and burning metal, as well as, secondarily, caused by the fire of the vehicle and exploding ammunition. Combustion products cause irreversible damage in the respiratory tract.

In addition to the above-mentioned acute effects, which are the most crucial for the fate of the crew of the vehicle destroyed, in the case of the use of the ammunition with a DU core, it is possible to encounter toxicological and radiologic risks in the area of the target and its surroundings. In the course of the core combustion, an aerosol of the smoke of burning oxidation products is produced. Studies have shown that DU penetrators hitting armored targets convert $17 \%-28 \%$ of the projectile mass into DU aerosols $[7,13,14]$. This is a mixture of uranium oxides, $\mathrm{UO}_{2}, \mathrm{UO}_{3}$ and $\mathrm{U}_{3} \mathrm{O}_{8}$, which are important in terms of pathological physiology [6]. Through particular points of entrance, uranium oxide particles enter the organism, which exert a considerable chemical toxicity, on the one hand, and also weak radioactivity, on the other. However, it should be noted that aerosols produced by the impact of DU penetrators on armor will contain not only DU, but also other metals present in the target.

The radiotoxicity represents a risk of chronic, late effects due to the internal irradiation of sensitive organs with uranium oxides and their daughter products. Radiation exposure can originate either from external sources, e.g., in an area contaminated with uranium from projectiles that missed their targets, or deposited uranium oxides released from damaged tanks, as well as from internal sources, like uranium taken up by inhalation of uranium oxides aerosols or the ingestion of contaminated food or water [7].

The aerosol cloud that is released at the moment the target is hit by the ammunition and for a short time period after that is particularly dangerous. Moderately radioactive dust components settle to the ground surface after the explosion, and by the action of rain and wind, they contaminate the soil and can enter underground water [15]. The DU can thus enter the human organism through the food chain. 
Children are particularly vulnerable to uranium exposure; contact with DU in war zones or groundwater contamination are the most likely exposure scenarios [16].

\section{Fate of Depleted Uranium in the Organism}

DU can be taken into the body through inhalation, ingestion, wound contamination and injected fragments. Generally, absorption is increased with the increased solubility of the compound. Uranium oxides $\left(\mathrm{U}_{3} \mathrm{O}_{8}, \mathrm{UO}_{2}\right)$ are relatively insoluble while uranium trioxide $\left(\mathrm{UO}_{3}\right)$ is more soluble [12].

During inhalation, DU particles are captured in the oropharynx and are either swallowed or reach, depending on their size (aerosol mainly comprises particles of micrometer size), the lower airways [7,17,18], where they are subjected to alveolar absorption [11]. Thus, they represent a considerable health risk. The dust of uranium oxides has a biological half-life in the alveoli of about 3.85 years [19]. The penetration of the particles down to the lung alveoli occurs in particle sizes up to $5 \mu \mathrm{m}$. The general opinion is that the inhalation of the dust is the most important means of exposure [20]. Importantly, research based on uranium processing plant workers has estimated that only $1 \%-5 \%$ of inhaled uranium particles will actually reach the lungs [1]. Uranium compounds entering the organism through the gastric wall or lungs are degraded in body liquids, where tetravalent uranium is oxidized to hexavalent uranium and uranyl ions are produced [12]. After absorption, uranium is included in a series of chemical reactions, leading to the production of oxides, hydroxides or carbonates [6]. In terms of a special uranium metabolism, there is a considerable production of complexes with citrates, bicarbonates and plasma proteins [21] and deposition, particularly in the bones, liver, kidneys and further tissues, which can result in unexpected pathological physiological processes, due to the chronic exposure. DU passes through the hematoencephalic barrier and is accumulated in the cerebral cortex, depending on the entrance way $[22,23]$.

A further potential exposure of organisms to DU can occur through open wounds, shrapnel or through contact with the skin [24,25]. Fragment sizes of $1 \mathrm{~cm}$ and above are indicated for surgical extirpation. Large fragments and others that are easily accessible, such as in soft tissue, are removed where possible to minimize the amount of uranium that will remain in fragments in the body. Over time the fragment sizes will decrease as the uranium leaches from these fragments [12].

DU is eliminated in urine, and thus, the kidneys belong to the group of the most damaged organs. The fact that uranium can be detected in the urine as long as nine years after exposure is a sufficient demonstration of the long-term internal contamination and tissue deposition of the substance in the organism [26,27].

\section{Depleted Uranium Toxicity}

Differences in the DU toxicity are associated with its solubility [12]. Soluble forms of uranium, which are absorbed within a few days, are rather associated with chemical toxicity, whereas the insoluble forms, which are typically absorbed for time periods of months to years, are associated with radiation toxicity [5]. Insoluble compounds are hazardous to the respiratory system (degeneration of the lung epithelium, hemorrhage) and soluble compounds are particularly renal toxins (they are manifested by the degeneration of the functional parts of the kidneys and by damaging the gastrointestinal tract). 
Given the physical-chemical characteristics of DU, it is impossible to accurately separate possible toxic effects of the action of DU in the human organism from factors that are associated with the radiation toxicity. These are typically mutagenic effects, which can be theoretically included into both groups of toxic effect manifestations.

\section{Radiation Toxicity}

Radiation toxicity is the decisive factor for long-term damage to the organism due to the slow absorption of uranium oxides by the lungs and the long-term retention in tissues of important visceral organs.

The radiologic toxicity of DU comes from the absorption of sufficient energy from ionizing radiation to change the structure of molecules within cells, including their DNA. The damage caused can be beyond the cell's capacity to repair itself. These cells may die, or the damaged cells may lead to cancer, or, if the reproductive cells are involved, to genetic changes [1].

Chronic effects of deposited uranium oxide particles are induced by the internal irradiation of sensitive organs in the course of radioactive disintegrations, which are all accompanied by alpha-particle radiation [3]. Alpha particles are a form of ionizing radiation; they do not have the capacity to penetrate the outer layer of the skin. Consequently, they only pose a radiation risk when they are taken into the body [1].

The main radiologic risk from inhaled DU is the development of lung cancer as a result of alpha radiation, but it has been estimated that it takes at least 10 years after exposure and perhaps even longer before this risk is realized [1]. By virtue of the fact that ingested DU is excreted rapidly, the exposure of it, as opposed to inhaled DU, does not pose a serious radiological risk [1].

\section{Chemical Toxicity}

The uranium chemical toxicity is independent of its isotopic abundance and is thus identical in the natural, enriched, as well as DU forms.

The chemical toxicity is characterized by general health problems, which are induced by changes in the kidneys, liver, lungs and the hematopoietic system. Depending on the chemical form, the LD50 of uranium for a man was found to be about $14 \mathrm{mg} / \mathrm{kg}$ [20,28].

The destruction of liver tissue and induction of hematological disorders have also been shown in certain studies in laboratory animals [9,29-31].

Laboratory studies, moreover, demonstrated that DU could induce immunological damage in rats, which were administered with a dose of DU of $130 \mathrm{mg} / \mathrm{kg}$ for a period of four months. The immunological damage was characterized by pathomorphological changes in immune organs and significantly lower thymic and splenic relative weights. In addition, higher uranium exposures also resulted in reduced numbers of peripheral lymphocytes, lower lymphocyte proliferation and reduced paw swelling [32]. The purpose of another study was to assess the immunological changes after long-term exposures to various doses of DU in mice. The results of this study also showed that a chronic intake of higher doses of DU $(300 \mathrm{mg} / \mathrm{kg})$ had a significant impact on the immune function, most likely due to an imbalance in T helper (Th), Th1 and Th2 cytokines [33]. 
One of the most recent studies dealt with the underlying mechanisms of DU toxicity in liver mitochondria. In this study, liver mitochondria were obtained from Wistar rats treated with DU in the form of uranyl acetate $(0.5,1$ or $2 \mathrm{mg} / \mathrm{kg}$, administered intraperitoneally) by using differential centrifugation. During in vitro experiments, control rat liver mitochondria were incubated with different concentrations of uranyl acetate $(50,100$ or $200 \mu \mathrm{M}$ ) for one hour. Uranyl acetate (a soluble salt of DU) induced succinate-supported mitochondrial reactive oxygen species production and elevated lipid peroxidation levels, glutathione oxidation and mitochondrial complex II inhibition. Uranyl acetate also induced mitochondrial permeability transition and an increase in cytochrome c release, which subsequently disturbed oxidative phosphorylation and reduced the mitochondrial adenosine triphosphate (ATP) concentration. Results of the study suggest that mitochondrial oxidative stress and the uncoupling of oxidative phosphorylation may play key roles in DU-induced hepatic toxicity [34].

In comparison to other organs, the kidney is known as the most sensitive target organ to DU toxicity. After the ingestion or inhalation of high DU doses (acute exposure), acute renal failure occurs, due to tubular necrosis. After high-dose exposure, acute tubular nephritis is observed, as indicated by proteinuria and a decreased glomerular filtration rate. In several studies, disorders of the renal function and damage to the kidney structure were also demonstrated in rats due to a chronic exposure to low DU doses [35-37]. The results of in vivo and in vitro studies based on isolated rat kidney mitochondria showed that uranyl acetate-induced nephrotoxicity is linked to the impairment of the electron transfer chain, especially at complexes II and III, which leads to subsequent oxidative stress. Mitochondrial reactive oxygen species production contributes to the nephrotoxicity of uranyl acetate, as it leads to the failure of oxidative phosphorylation, ATP cellular declination, mitochondrial membrane potential disruption, mitochondrial swelling, damage to the mitochondrial outer membrane integrity and, finally, to the release of cytochrome $\mathrm{c}$ from mitochondria. In addition, increased reactive oxygen species production, lipid peroxidation, glutathione depletion and a potential collapse in the mitochondrial membrane were also observed in kidney mitochondria following uranyl acetate injection. These results can justify oxidative damage and nephrotoxicity caused by uranium compounds [38].

During chronic exposures to low levels of DU, the use of some sensitive and specific biomarkers (substances that can be objectively measured and are recognized as indicators of normal biological or pathological processes), such as beta 2-microglobulin or tubular enzymes, would be useful, particularly when the injury is slight. Recent experimental studies in the laboratory showed the relevance of such new biomarkers as Kim-1 to detect slight renal injury [39].

As already mentioned, nephrotoxicity belongs to the most considerable toxic effects of DU. Due to this, scientific experiments focused on the study of suitable antidotes for the case of intoxication with DU. Zinc is considered to be one of the most efficient antidotes in the case of poisoning with heavy metals. Its positive effects were also demonstrated in the case of the intoxication with DU, where pre-treatment with zinc significantly inhibited DU-induced cell apoptosis in human kidney cells (HK-2) [40]. In another experiment, the ability of two antioxidants, beta-glucan and butylated hydroxyl toluene, to prevent uranyl acetate-induced mitochondrial dysfunction by using isolated rat kidney mitochondria was examined. The results demonstrated that beta-glucan may be a mitochondria-targeting antioxidant and suggested this compound as a possible drug candidate for the prophylaxis and treatment of DU-induced nephrotoxicity [41]. In addition to antidotes, the elimination of uranium from the human body can be accelerated by the administration of chelating agents. One of the possible substances tested was BPCBG 
( $N, N^{\prime}$-1,2-ethanediylbis[ $N$-[(2,3-dihydroxyphenyl)methyl]]-glycine). In experimental studies, this substance exerted a higher efficacy compared to commonly used DTPA-CaNa3 (diethylenetriaminepentaacetic acid calcium trisodium) [42].

DU neurotoxicity has not yet been definitely demonstrated in humans, but certain experimental studies in laboratory animals suggest that there is an association between the neurotoxic effects and DU exposure [22,23]. There is also an experimental demonstration that DU causes behavioral effects, since after the DU exposure, the behavior of rats was affected $[22,43]$. A recent laboratory study suggested that mitochondrial oxidative stress and the impairment of oxidative phosphorylation in brain mitochondria may play a key role in DU neurotoxicity [44].

In experimental animals, the exposure to uranium inhibits the reproduction activity and disturbs intrauterine development. If uranium is administered orally or subcutaneously to mice, a reduction in their fertility can be observed. Teratogenic DU effects have not yet been definitely demonstrated in laboratory animals. There is also embryonic and fetal toxicity, and in the offspring, there is a reduction in the growth rate and the production of malformations, such as cleft palate and skeleton defects $[24,45]$. The animals received diets comprising DU (4 mg/kg DU daily and $40 \mathrm{mg} / \mathrm{kg}$ DU daily) for four months prior to mating. After four months of exposure, there was a considerable drop in the pregnancy rate, normal delivery rate and survival rate compared to controls. These parameters fell by half to two-thirds, while no adverse effects were evident in controls. There were also statistically significantly higher DU levels in the ovaries and testes compared to the control generation. The sex hormone levels in the blood serum were also affected in both generations, and the levels of enzymes active in spermiogenesis were also significantly different between the two generations [46].

Other studies using the offspring of female and male rats surgically implanted with DU pellets revealed no gross physical abnormalities attributable to prenatal uranium exposure. Elevations of the urinary uranium concentrations, confirming in vivo solubility of the implanted pellets, were observed in the parent generation. Neurodevelopment and immune function assessments of the first generation offspring were normal [47]. In a follow up study of the second-generation offspring, development was normal, and no gross abnormalities were observed. As with the first generation offspring, no instances of thorax malformation were observed at necropsy. In general, it appears that imbedded DU is not a reproductive or developmental hazard. However, the elevated heart masses of the first- and second-generation offspring suggest it may be precautionary to not totally discount the possibility of teratogenic effects $[48,49]$. The results of another study suggest that implantation of up to 20 DU pellets of $1 \times 2 \mathrm{~mm}$ size in rats for approximately $21 \%$ of their adult lifespan does not have an adverse impact on male reproductive success, sperm concentration, or sperm velocity [50] and on their general health and neurobehavioral capacities [51]. The effects on postnatal development and behavior were assessed in the offspring of female rats concurrently exposed to uranium and restraint stress. Adult female rats were administered uranyl acetate dihydrate in the drinking water at doses of 0,40 and $80 \mathrm{mg} /(\mathrm{kg}$ day) for four weeks before mating with untreated males, as well as during pregnancy and lactation. The results of that study indicate that, in general terms, exposure of female rats to uranyl acetate dihydrate before mating with untreated males, as well as during gestation and lactation, did not cause relevant dose-related adverse effects on postnatal development and behavior of the offspring [52]. 


\section{Epidemiologic Study}

Epidemiologic studies are essential for assessing the relationship between exposure to DU and health outcomes and should be focused on the health impacts for those in the civilian population and military veterans [1].

No adverse health effect can be attributed to DU until it is first confirmed that an individual has really been exposed to DU. Presently it is not possible to accurately measure the amount of DU that a soldier might have been exposed to on the battlefield. The one exception is a cohort of U.S. soldiers involved in friendly fire incidents during the Gulf War, who still have DU shrapnel in their bodies and who have since been closely monitored [1].

A biennial health surveillance program established by the U.S. Department of Veteran Affairs for a group of Veterans who had been exposed to DU during the 1991 Gulf War through friendly-fire incidents involving DU munitions and vehicles protected by DU armor, has shown continuously elevated urine DU concentrations in the subset of veterans with embedded fragments for over 20 years. Few clinically significant health effects were observed related to long-term, low-dose DU exposure from embedded shrapnel. Renal biomarkers showed minimal effects on proximal tubular function and cytotoxicity, and pulmonary functions remained within the normal clinical ranges [25]. Further scientific research performed in a population of veterans from the Gulf War (1991) showed that the inhalation of DU exposure did not induce long-term adverse pulmonary effects in the soldiers [53]. Likewise, no significant evidence of clinically important changes was observed in kidney or bone [54]. Based on the results of a study in which 35 veterans from the First Gulf War with embedded DU fragments and/or inhalation exposure participated, it is obvious that chronic exposure to DU did not induce chromosomal aberrations in the peripheral blood lymphocytes [55].

Despite this, there are also epidemiological studies that found an increased frequency of micronuclei formation [56] or other chromosomal instability [57-59] in the exposed population and military veterans from wars in the Balkans and the Gulf War. Another study showed, for example, increased incidences of various types of cancer and birth defects among civilians living in those affected areas [60-66]. These studies suggest that DU exposure is either a primary cause or related to the main cause of congenital anomalies and increased rates of cancer.

It is difficult to detect an increased cancer risk due to radiation at doses lower than $100 \mathrm{mSv}$ due to the excess risk at low doses being small in comparison to spontaneous rates of cancers of the same type [5]. As the increase in cancer occurrences being high (by a factor of two to five) in the above-mentioned cases, it is possible that these negative effects were also caused by other factors (e.g., biological or chemical agents, etc.).

After the various military conflicts in which DU was used, studies were conducted to evaluate whether there were/are grounds for concern about the health hazards of DU for military members and civilians. These epidemiological studies that have examined the levels of uranium in the urine of these groups have come to the conclusion that there were no significant exposure amounts of DU [67-71].

Studies were not limited to only military field DU ingestion, but also examined civilian life, as in the case of the release of DU in fire. An example of this kind of events took place in 1992 in Amsterdam, as a cargo plane using DU as a ballast crashed. The plane was carrying $282 \mathrm{~kg}$ of DU as the ballast, but only $130 \mathrm{~kg}$ was recovered. It was assumed that the remainder was consumed in the fire, which created 
the possibility that uranium oxide particles had been dispersed through dust and smoke and were subsequently inhaled or ingested. A follow-up study, which began in 2000 and was attended by 2499 workers (firefighters, police officers, hangar workers) involved in the liquidation of the accident, revealed significantly elevated concentrations of uranium in their urine compared with untreated workers. Impaired renal function parameters were also found [72].

From the results of most epidemiologic studies, it follows that the association between the use of DU ammunition and oncological or other diseases of soldiers from the Gulf War, as well as from the Balkan Wars $[1,73,74]$, has not yet been conclusively demonstrated. There is also no convincing evidence that the use of the DU ammunition is dangerous to the civilian population in areas of former military activity $[1,12,75]$.

\section{Conclusions}

Although individual scientific studies brought a number of negative DU effects from nephrotoxicity through potential mutagenic and carcinogenic effects, in general, epidemiologic studies performed on war veterans and civil populations are restricted to the small size of the samples and the heterogeneous natures of the groups. Similar drawbacks are also associated with studies dealing with DU teratogenic effects. Limitations of the datasets are again the inadequate sample sizes and statistical powers, inadequate exposure assessments and substantial potentials for recall biases and exposure misclassifications.

Important observations on the effects of DU might be derived from in vivo animal studies. For example, they may provide information on growth, reproductive capacity, cancer, neurobehavioral function and transplacental exposure. Animal studies focusing on the health effects of DU on the progeny's health might be useful for corroborating findings reported in epidemiologic studies.

The results of the above-mentioned studies suggest that the most important toxic mechanism of DU toxicity is the involvement of oxidative stress and reactive oxygen species. In the development of cellular oxidative damage to most types of mammalian cells, the major sources of reactive oxygen species are mitochondria and also key organelles. Experimental studies demonstrated a significant mitochondrial membrane potential collapse and mitochondrial swelling after DU exposure in different cell lines. Therefore, mitochondrial dysfunction and oxidative damage may be responsible for the pathological consequences of DU exposure in living organism.

The critical route of DU exposure in humans is through aerosol inhalation. The acute health risk is particularly due to the chemical toxicity. In addition to the chemical toxicity, DU exerts radiotoxic effects induced by $\alpha$-particle radiation. The short range of this type of ionizing radiation is the cause of the relative safety of handling DU ammunition, but not in the case of ingestion or inhalation, as compared to other radiation types, i.e., $\beta$-radiation and $\gamma$ products of global and local fallout from nuclear explosions.

It is important to pay extraordinary attention to this type of ammunition in its whole life cycle, i.e., from the development, production, storing, transfer, over peaceful use in tests and trainings through military practices. It is necessary to implement further studies, which would be focused on health and environmental risks associated with DU exposure, primarily oriented toward the local population and soldiers that were exposed to DU inhalation. A response to the question associated with the magnitude of the risk could be obtained from the combined results of laboratory and epidemiological studies. 


\section{Acknowledgments}

This work was supported by Project No. VG20102015002, Ministry of the Interior of the Czech Republic.

\section{Author Contributions}

The authors contributed equally to this work. All authors have read, edited, and approved the final version of the paper.

\section{Conflicts of Interest}

The authors declare no conflict of interest.

\section{References}

1. Scientific Advisory Committee on Veterans' Health. Depleted Uranium and Canadian Veterans-A Review of Potential Exposure and Health Effects-A Report Prepared for the Minister of Veterans Affairs, 2013. Available online: http://www.veterans.gc.ca/pdf/Reports/ scientific-advisory/2013-du-veterans.pdf (accessed on 15 July 2014).

2. U.S. Department of Health and Human Services Public Health Service. Toxicological Profile for Uranium; Agency for Toxic Substances and Disease Registry: Atlanta, GA, USA, 2013. Available online: http://www.atsdr.cdc.gov/toxprofiles/TP.asp?id=440\&tid=77 (accessed on 15 July 2014).

3. Streda, L. Attempts to explain so called "Balkan syndrome" are still under way. Mezinárodní Politika 2001, 25, 31-35. (In Czech)

4. Sztajnkrycer, M.D.; Otten, E.J. Chemical and radiological toxicity of depleted uranium. Mil. Med. 2004, 169, 212-216.

5. Bleise, A.; Danesi, P.R.; Burkart, W. Properties, use and health effects of depleted uranium (DU): A general overview. J. Environ. Radioact. 2003, 64, 93-112.

6. Craft, E.; Abu-Qare, A.; Flaherty, M.; Garofolo, M.; Rincavage, H.; Abou-Donia, M. Depleted and natural uranium: Chemistry and toxicological effects. J. Toxicol. Environ. Health B Crit. Rev. 2004, 7, 297-317.

7. Bem, H.; Bou-Rabee, F. Environmental and health consequences of depleted uranium use in the 1991 Gulf War. Environ. Int. 2004, 30, 123-134.

8. World Health Organization (WHO). Sources, Exposure and Health Effects; WHO/SDE/PHE/01.1; WHO: Geneva, Switzerland, 2001.

9. Matousek, J. Military-technical, medical and international aspects of the use of ammunition with the depleted uranium core. Mezinárodní Politika 2001, 25, 32-37. (In Czech)

10. Bolton, J.P.; Foster, C.R. Battlefield use of depleted uranium and the health of veterans. Trauma 2002, 4, 1-10.

11. Briner, W. The toxicity of depleted uranium. Int. J. Environ. Res. Public Health 2010, 7, 303-313.

12. Burkart, W.; Danesi, P.R.; Hendry, J.H. Properties, use and health effects of depleted uranium. Int. Congr. Ser. 2005, 1276, 133-136.

13. Jiang, G.C.; Aschner, M. Depleted Uranium. In Handbook of Toxicology of Chemical Warfare Agents; Gupta, R.C., Ed.; Elsevier: San Diego, CA, USA, 2009; pp. 393-406. 
14. Parkhurst, M.A. Measuring aerosols generated inside armoured vehicles perforated by depleted uranium ammunition. Radiat. Prot. Dosim. 2003, 105, 167-170.

15. Oliver, I.W.; Graham, M.C.; MacKenzie, A.B.; Ellam, R.M.; Farmer, J.G. Depleted uranium mobility across a weapons testing site: Isotopic investigation of porewater, earthworms, and soils. Environ. Sci. Technol. 2008, 42, 9158-9164.

16. Homma-Takeda, S.; Kokubo, T.; Terada, Y.; Suzuki, K.; Ueno, S.; Hayao, T.; Inoue, T.; Kitahara, K.; Blyth, B.J.; Nishimura, M.; et al. Uranium dynamics and developmental sensitivity in rat kidney. J. Appl. Toxicol. 2013, 33, 685-694.

17. Mitsakou, C.; Eleftheriadis, K.; Housiadas, C.; Lazaridis, M. Modelling of the dispersion of depleted uranium aerosol. Health Phys. 2003, 84, 538-544.

18. Salbu, B.; Janssens, K.; Lind, O.C.; Proost, K.; Danesi, P.R. Oxidation states of uranium in DU particles from Kosovo. J. Environ. Radioact. 2003, 64, 167-173.

19. Durakovic, A.; Horan, P.; Dietz, L.A.; Zimmerman, I. Estimate of the time zero lung burden of depleted uranium in Persian Gulf War veterans by the 24-hour urinary excretion and exponential decay analysis. Mil. Med. 2003, 168, 600-605.

20. Briner, $\mathrm{W}$. The evolution of depleted uranium as an environmental risk factor: Lessons from other metals. Int. J. Environ. Res. Public Health 2006, 3, 129-135.

21. Cooper, J.R.; Stradling, G.N.; Smith, H.; Ham, S.E. The behaviour of uranium-233 oxide and uranyl-233 nitrate in rats. Int. J. Radiat. Biol. Relat. Stud. Phys. Chem. Med. 1982, 41, 421-433.

22. Barber, D.S.; Hancock, S.K.; McNally, A.M.; Hinckley, J.; Binder, E.; Zimmerman, K.; Ehrich, M.F.; Jortner, B.S. Neurological effects of acute uranium exposure with and without stress. Neurotoxicology 2007, 28, 1110-1119.

23. Monleau, M.; Bussy, C.; Lestaevel, P.; Houpert, P.; Paquet, F.; Chazel, V. Bioaccumulation and behavioural effects of depleted uranium in rats exposed to repeated inhalations. Neurosci. Lett. 2005, 390, 31-36.

24. Hindin, R.; Brugge, D.; Panikkar, B. Teratogenicity of depleted uranium aerosols: A review from an epidemiological perspective. Environ. Health 2005, 4, 17-19.

25. McDiarmid, M.A.; Gaitens, J.M.; Hines, S.; Breyer, R.; Wong-You-Cheong, J.J.; Engelhardt, S.M.; Oliver, M.; Gucer, P.; Kane, R.; Cernich, A.; et al. The Gulf War depleted uranium cohort at 20 years: Bioassay results and novel approaches to fragment surveillance. Health Phys. 2013, 104, 347-361.

26. Horan, P.; Dietz, L.; Durakovic, A. The quantitative analysis of depleted uranium isotopes in British, Canadian, and U.S. Gulf War veterans. Mil. Med. 2002, 167, 620-627.

27. McDiarmid, M.A.; Keogh, J.P.; Hooper, F.J.; McPhaul, K.; Squibb, K.; Kane, R.; DiPino, R.; Kabat, M.; Kaup, B.; Anderson, L.; et al. Health effects of depleted uranium on exposed Gulf War veterans. Environ. Res. 2000, 82, 168-180.

28. Kathren, R.L.; Burklin, R.K. Acute chemical toxicity of uranium. Health Phys. 2008, 94, 170-179.

29. Gilman, A.P.; Moss, M.A.; Villeneuve, D.C.; Secours, V.E.; Yagminas, A.P.; Tracy, B.L.; Quinn, J.M.; Long, G.; Valli, V.E. Uranyl nitrate: 91-day exposure and recovery studies in the male New Zealand white rabbit. Toxicol. Sci. 1998, 41, 138-151.

30. Gilman, A.P.; Villeneuve, D.C.; Secours, V.E.; Yagminas, A.P.; Tracy, B.L.; Quinn, J.M.; Valli, V.E.; Moss, M.A. Uranyl nitrate: 91-day toxicity studies in the New Zealand white rabbit. Toxicol. Sci. 1998, 41, 129-137. 
31. Gilman, A.P.; Villeneuve, D.C.; Secours, V.E.; Yagminas, A.P.; Tracy, B.L.; Quinn, J.M.; Valli, V.E.; Willes, R.J.; Moss, M.A. Uranyl nitrate: 28-day and 91-day toxicity studies in the Sprague-Dawley rat. Toxicol. Sci. 1998, 41, 117-128.

32. Hao, Y.H.; Ren, J.; Li, R.; Liu, J.; Yang, Z.Y.; Su, Y.P. Immunological changes associated with chronic ingestion of depleted uranium in rats. Health Phys. 2013, 105, 3-10.

33. Hao, Y.; Ren, J.; Liu, J.; Yang, Z.; Liu, C.; Li, R.; Su, Y. Immunological changes of chronic oral exposure to depleted uranium in mice. Toxicology 2013, 309, 81-90.

34. Shaki, F.; Hosseini, M.J.; Shahraki, J.; Ghazi-Khansari, M.; Pourahmad, J. Toxicity of depleted uranium on isolated liver mitochondria: A revised mechanistic vision for justification of clinical complication of depleted uranium (DU) on liver. Toxicol. Environ. Chem. 2013, 95, 1221-1234.

35. Berradi, H.; Bertho, J.M.; Dudoignon, N.; Mazur, A.; Grandcolas, L.; Baudelin, C.; Grison, S.; Voisin, P.; Gourmelon, P.; Dublineau, I. Renal anemia induced by chronic ingestion of depleted uranium in rats. Toxicol. Sci. 2008, 103, 397-408.

36. Zhu, G.; Tan, M.; Li, Y.; Xiang, X.; Hu, H.; Zhao, S. Accumulation and distribution of uranium in rats after implantation with depleted uranium fragments. J. Radiat. Res. 2009, 50, 183-192.

37. Zhu, G.; Xiang, X.; Chen, X.; Wang, L.; Hu, H.; Weng, S. Renal dysfunction induced by long-term exposure to depleted uranium in rats. Arch. Toxicol. 2009, 83, 37-46.

38. Shaki, F.; Hosseini, M.J.; Ghazi-Khansari, M.; Pourahmad, J. Toxicity of depleted uranium on isolated rat kidney mitochondria. Biochim. Biophys. Acta 2012, 1820, 1940-1950.

39. Gueguen, Y.; Rouas, C. New data on uranium nephrotoxicity. Radioprotection 2012, 47, 345-359.

40. Hao, Y.; Ren, J.; Liu, C.; Li, H.; Liu, J.; Yang, Z.; Li, R.; Su, Y. Zinc Protects Human kidney cells from depleted uranium-induced apoptosis. Basic Clin. Pharmacol. Toxicol. 2013, 114, 271-280.

41. Shaki, F.; Pourahmad, J. Mitochondrial toxicity of depleted uranium: Protection by $\beta$-glucan. Iran. J. Pharm. Res. 2013, 12, 131-140.

42. Bao, Y.; Wang, D.; Li, Z.; Hu, Y.; Xu, A.; Wang, Q.; Shao, C.; Chen, H. Efficacy of a novel chelator BPCBG for removing uranium and protecting against uranium-induced renal cell damage in rats and HK-2 cells. Toxicol. Appl. Pharmacol. 2013, 15, 17-24.

43. Briner, W.; Murray, J. Effects of short-term and long-term depleted uranium exposure on open-field behavior and brain lipid oxidation in rats. Neurotoxicol. Teratol. 2005, 27, 135-144.

44. Shaki, F.; Hosseini, M.J.; Ghazi-Khansari, M.; Pourahmad, J. Depleted uranium induces disruption of energy homeostasis and oxidative stress in isolated rat brain mitochondria. Metallomics 2013, 5, 736-744.

45. Domingo, J.L. Reproductive and developmental toxicity of natural and depleted uranium: A review. Reprod. Toxicol. 2001, 15, 603-609.

46. Hao, Y.; Li, R.; Leng, Y.; Ren, J.; Liu, J.; Ai, G.; Xu, H.; Su, Y.; Cheng, T. The reproductive effects in rats after chronic oral exposure to low-dose depleted uranium. J. Radiat. Res. 2012, 53, 377-384.

47. Arfsten, D.P.; Bekkedal, M.; Wilfong, E.R.; Rossi, J.; Grasman, K.A.; Healey, L.B.; Rutkiewicz, J.M.; Johnson, E.W.; Thitoff, A.R. Study of the reproductive effects in rats surgically implanted with depleted uranium for up to 90 days. J. Toxicol. Environ. Health A 2005, 68, 967-997. 
48. Arfsten, D.P.; Still, K.R.; Wilfong, E.R.; Johnson, E.W.; McInturf, S.M.; Eggers, J.S.; Schaeffer, D.J.; Bekkedal, M.Y. Two-generation reproductive toxicity study of implanted depleted uranium (DU) in CD rats. J. Toxicol. Environ. Health 2009, 72, 410-427.

49. Katz, S.A. The Chemistry and Toxicology of Depleted Uranium. Toxics 2014, 2, 50-78.

50. Arfsten, D.P.; Schaeffer, D.J.; Johnson, E.W.; Robert Cunningham, J.; Still, K.R.; Wilfong, E.R. Evaluation of the effect of implanted depleted uranium on male reproductive success, sperm concentration, and sperm velocity. Environ. Res. 2006, 100, 205-215.

51. Arfsten, D.P.; Wilfong, E.R.; Bekkedal, M.Y.; Johnson, E.W.; McInturf, S.M.; Eggers, J.S.; Schaeffer, D.J.; Still, K.R. Evaluation of the effect of implanted depleted uranium (DU) on adult rat behavior and toxicological endpoints. J. Toxicol Environ. Health A 2007, 70, 1995-2010.

52. Sánchez, D.J.; Bellés, M.; Albina, M.L.; Gómez, M.; Linares, V.; Domingo, J.L. Exposure of pregnant rats to uranium and restraint stress: Effects on postnatal development and behavior of the offspring. Toxicology 2006, 228, 323-332.

53. Hines, S.E.; Gucer, P.; Kligerman, S.; Breyer, R.; Centeno, J.; Gaitens, J.; Oliver, M.; Engelhardt, S.; Squibb, K.; McDiarmid, M. Pulmonary health effects in Gulf War I service members exposed to depleted uranium. J. Occup. Environ. Med. 2013, 55, 937-944.

54. McDiarmid, M.A.; Engelhardt, S.M.; Dorsey, C.D.; Oliver, M.; Gucer, P.; Gaitens, J.M.; Kane, R.; Cernich, A.; Kaup, B.; Hoover, D.; et al. Longitudinal health surveillance in a cohort of Gulf War veterans 18 years after first exposure to depleted uranium. J. Toxicol Environ. Health A 2011, 74, 678-691.

55. Bakhmutsky, M.V.; Squibb, K.; McDiarmid, M.; Oliver, M.; Tucker, J.D. Long-term exposure to depleted uranium in Gulf-War veterans does not induce chromosome aberrations in peripheral blood lymphocytes. Mutat. Res. 2013, 757, 132-139.

56. Ibrulj, S.; Krunic-Haveric, A.; Haveric, S.; Pojskic, N.; Hadziselimovic, R. Micronuclei occurrence in population exposed to depleted uranium and control human group in correlation with sex, age and smoking habit. Med. Arh. 2004, 58, 335-338.

57. Milacic, S. Health investigations of depleted-uranium clean-up workers. Med. Lav. 2008, 99, 366-370.

58. Milacic, S.; Simic, J. Identification of health risks in workers staying and working on the terrains contaminated with depleted uranium. J. Radiat. Res. 2009, 50, 213-222.

59. Schröder, H.; Heimers, A.; Frentzel-Beyme, R.; Schott, A.; Hoffmann, W. Chromosome aberration analysis in peripheral lymphocytes of Gulf War and Balkans War veterans. Radiat. Prot. Dosim. 2003, 103, 211-219.

60. Aitken, M. Gulf war leaves legacy of cancer. BMJ 1999, doi:10.1136/bmj.319.7207.401a.

61. Alaani, S.; Tafash, M.; Busby, C.; Hamdan, M.; Blaurock-Busch, E. Uranium and other contaminants in hair from the parents of children with congenital anomalies in Fallujah, Iraq. Confl. Health 2011, doi:10.1186/1752-1505-5-15.

62. Al-Hamzawi, A.A.; Jaafar, M.S.; Tawfiq, N.F. Uranium concentration in blood samples of Southern Iraqi leukemia patients using CR-39 track detector. J. Radioanal. Nucl. Chem. 2014, 299, 1267-1272.

63. Busby, C.; Hamdan, M.; Ariabi, E. Cancer, infant mortality and birth sex-ratio in Fallujah, Iraq 2005-2009. Int. J. Environ. Res. Public Health 2010, 7, 2828-2837. 
64. Fathi, R.A.; Matti, L.Y.; Al-Salih, H.S.; Godbold, D. Environmental pollution by depleted uranium in Iraq with special reference to Mosul and possible effects on cancer and birth defect rates. Med. Confl. Surviv. 2013, 29, 7-25.

65. Obralić, N.; Gavrankapetanović, F.; Dizdarević, Z.; Durić, O.; Sisić, F.; Selak, I.; Balta, S.; Nakas, B. The number of malignant neoplasm in Sarajevo region during the period 1998-2002. Med. Arh. 2004, 58, 275-278.

66. Papathanasiou, K.; Gianoulis, C.; Tolikas, A.; Dovas, D.; Koutsos, J.; Fragkedakis, N.; Papathanasiou, N. Effect of depleted uranium weapons used in the Balkan war on the incidence of cervical intraepithelial neoplasia (CIN) and invasive cancer of the cervix in Greece. Clin. Exp. Obstet. Gynecol. 2005, 32, 58-60.

67. Bland, D.; Rona, R.; Coggon, D.; Anderson, J.; Greenberg, N.; Hull, L.; Wessely, S. Urinary isotopic analysis in the UK Armed Forces: No evidence of depleted uranium absorption in combat and other personnel in Iraq. Occup. Environ. Med. 2007, 64, 834-838.

68. Cazoulat, A.; Lecompte, Y.; Bohand, S.; Castagnet, X.; Laroche, P. Urinary uranium analysis results on Gulf war or Balkans conflict veterans. Pathol. Biol. 2008, 56, 77-83.

69. Dorsey, C.D.; Engelhardt, S.M.; Squibb, K.S.; McDiarmid, M.A. Biological monitoring for depleted uranium exposure in U.S. Veterans. Environ. Health Perspect. 2009, 117, 953-956.

70. Oeh, U.; Priest, N.D.; Roth, P.; Ragnarsdottir, K.V.; Li, W.B.; Höllriegl, V.; Thirlwall, M.F.; Michalke, B.; Giussani, A.; Schramel, P.; et al. Measurements of daily urinary uranium excretion in German peacekeeping personnel and residents of the Kosovo region to assess potential intakes of depleted uranium (DU). Sci. Total Environ. 2007, 381, 77-87.

71. Ough, E.A.; Lewis, B.J.; Andrews, W.S.; Bennett, L.G.; Hancock, R.G.; Scott, K. An examination of uranium levels in Canadian forces personnel who served in the Gulf War and Kosovo. Health Phys. 2002, 82, 527-532.

72. Bijlsma, J.A.; Slottje, P.; Huizink, A.C.; Twisk, J.W.; van der Voet, G.B.; de Wolff, F.A.; Vanhaecke, F.; Moens, L.; Smid, T. Urinary uranium and kidney function parameters in professional assistance workers in the Epidemiological Study Air Disaster in Amsterdam (ESADA). Nephrol. Dial. Transpl. 2008, 23, 249-255.

73. Bogers, R.P.; van Leeuwen, F.E.; Grievink, L.; Schouten, L.J.; Kiemeney, L.A.; Schram-Bijkerk, D. Cancer incidence in Dutch Balkan veterans. Cancer Epidemiol. 2013, 37, 550-555.

74. Storm, H.H.; Jørgensen, H.O.; Kejs, A.M.; Engholm, G. Depleted uranium and cancer in Danish Balkan veterans deployed 1992-2001. Eur. J. Cancer 2006, 42, 2355-2358.

75. Al-Hadithi, T.S.; Al-Diwan, J.K.; Saleh, A.M.; Shabila, N.P. Birth defects in Iraq and the plausibility of environmental exposure: A review. Confl. Health 2012, doi:10.1186/1752-1505-6-3.

(C) 2015 by the authors; licensee MDPI, Basel, Switzerland. This article is an open access article distributed under the terms and conditions of the Creative Commons Attribution license (http://creativecommons.org/licenses/by/4.0/). 